\title{
Behaviour of Millenial wine consumers in southern Serbia
}

\author{
Vladimir Radovanović, Jelena Petrović, and Blaga Radovanović \\ University of Niš, Faculty of Natural Sciences and Mathematics, Višegradska 33, 18000 Niš, Serbia
}

\begin{abstract}
Consumer behaviour when purchasing wine is the result of a complementary operation of the large number of different factors, which may include economic, geographic, social, psychological, and other. Discovering consumer preferences for wine and their buying behavior would allow the application of an appropriate marketing strategy to increase the sales of wine. Special attention was given to one of the most promising new demographic segments that likes to buy - Millennial generation. The main purpose of this research is to find out if the wine attributes of the Millennials are different from other generations in southern Serbia. Results of this research are shown that when choosing wine, the quality of wine has the biggest impact on consumers, rather than others wine attributes. The paper also asserts that, the wine industry should particularly focus on marketing to Millennial age group, as this segment has a high willingness to experiment.
\end{abstract}

\section{Introduction}

Wine is a product that has a high proportion of attributes that can only be assessed during consumption, experience attributes in other words, with the consequent ability of consumers to assess quality prior to purchase being severely impaired and resulting in consumers falling back on extrinsic cues to assess quality. Consumer behavior is the main field and source for Customer Relationship Management (CRM) programs [1]. A number of studies have been undertaken to investigate the interplay between the various wine attributes, such as product brand, region of origin, various packaging elements, grape variety, as well as other factors, such as price, consumption situation, or occasion, consumers' level of involvement with and knowledge of wine, consumption frequency, wine-related lifestyle segmentation, and so forth [2].

Consumer behavior when purchasing wine is the result of a complementary operation of the large number of different factors, which may include economic, geographic, social, psychological, and other. Literature relating to the behaviour of wine consumers focuses on the following two areas: factors affecting the behaviour of wine consumers and the factors that influence the decisionmaking process of consumers who buy wine [3]. A key consideration in exploring the wine consumer decisionmaking process and consumers' evaluation of alternatives is that wine attributes represent intrinsic and extrinsic cues for the consumer [4]. Sanchez and Gill [5] illustrate how consumers have preferences according to the bundle of benefits they are seeking.

Market segmentation or the process of dividing a market into meaningful, relatively similar and identifiable segments or groups is used in multiple industries [6].

Segmentation assists marketing researchers in analyzing the needs of a specific customer segment and it allows marketing campaigns to be focused on these identified needs [7]. Every generation has it's own characteristics. The changes in consumption expenditure can best be understood by taking a generation approach [8]. Different generations and demographic consumer groups are exposed to: (a) different social and economic opportunities and barriers, (b) different types of technology activities, (c) different social perceptions and different community norms, and (d) different life experiences and events [9].

One of the premiere studies on market segmentation was that of Bruwer and House [10], in which he focused on the geographic segment of consumers in the South Australian wine industry. A recent qualitative study conducted in the United States, in which segmentation focused on when and why consumers drink wine [7]. Regarding demographic segmentation, most consumer industries segment this category by the four generations: of Traditionalists (born between 1900 and 1945); Baby boomers (born between 1946 and 1964); Generation Xers (born between 1965 and 1977); and Millennials or Y generation or Echo boomers (born between 1977 and 2000) [11]. Atkin and Thach [12] were demonstrated how the marketing strategies of Millennials differ from older consumers.

Determining the specific factors that influence Millennials and their purchasing attitudes and patterns has become an important focus of consumer research as their potential spending power, the ability to be trendsetters, adoption to new products and potential for becoming a lifetime customer [7]. A majority of Millennials (56\%), Generation Xers (52\%) and Boomers (54\%) think technology helps people use their time more efficiently, Three-fourths (75\%) of Millennials have created a social networking profile compared with $50 \%$ of Generation X-ers, $30 \%$ of Boomers and $6 \%$ of members of the Silent generation [11].

In order to implement an appropriate marketing strategy, which would contribute to increased market share of domestic wine producers on the wine market, it is necessary to conduct appropriate marketing research of wine consumers in southern Serbia. At the same time, it is necessary to analyse the influence of wine attributes on 
Table 1. Demographic characteristic of the wine consumers.

\begin{tabular}{|l|c|c|}
\hline Age (year) & Sample numbers & Frequency (\%) \\
\hline $18-28$ & 830 & 48.7 \\
\hline $29-38$ & 313 & 18.4 \\
\hline $39-50$ & 262 & 15.4 \\
\hline $51-65$ & 300 & 17.6 \\
\hline
\end{tabular}

making a decision to purchase and consume wine, in order to understand the preferences of consumers, as well as their behavior.

This paper relies on the conducted marketing research in southern Serbia of wine consumers in order to identify the wine attributes that has a dominant influence on the wine purchasing decision. The main purpose of this research is to find out if the wine attributes of the Millennials are different from other generations in southern Serbia. The paper also asserts that, the wine industry should particularly focus on marketing to Millennial age group, as this segment has a high willingness to experiment.

\section{Research methodology}

\subsection{Samples}

The survey was carried out in the southern Serbia. Consumers were surveyed by personal interview, i.e. the "face to face" technique. 1,720 wine consumers were surveyed. After elimination of questionnaires with incomplete answers, we got a sample of 1,705 questionnaires.

\subsection{Statistical analysis}

Data collected by surveying wine consumers was entered in the SPSS database, and all further analyses were performed using the Statistical Package for the Social Sciences, SPSS. Data analysis relied on statistical methods, descriptive statistics, Chi-test and cluster analysis.

\section{Results and discussion}

With a view to help Serbia's producers of wine in selling their products on the domestic market, where is large competition high quality imported wine, were carried out this investigation. The first major question was whether the respondent likes wine, and what are the reasons to decide for certain types of wine.

The Table 1 shows the classification of consumers according to their age in the test region of Serbia. Millennials generation is the largest group of wine consumers with a total of $1143(67.1 \%)$. This segment group is divided into two subgroups: Generation $\mathrm{Y}_{1}$ from 1977 to 1986 (18.4\%). and Generation $\mathrm{Y}_{2}$ from 1987 to 1997 (48.7\%):

The largest number of samples of Millennials, Generation $\mathrm{Y}_{2}$ (830 consumers), who used in this research, were students in University of Niš (Serbia). The age wine consumers from 39 to 50 (Generation X-ers, 1965-1976) participated in $15.4 \%$, and from 51 to 65 year (Baby Boomers generation, 1950-1964) in 17.6\% (Fig. 1):

Table 2 shows that $50.76 \%$ of consumers in Generation $\mathrm{Y}_{2}$ make a decision to buy wine based on its quality

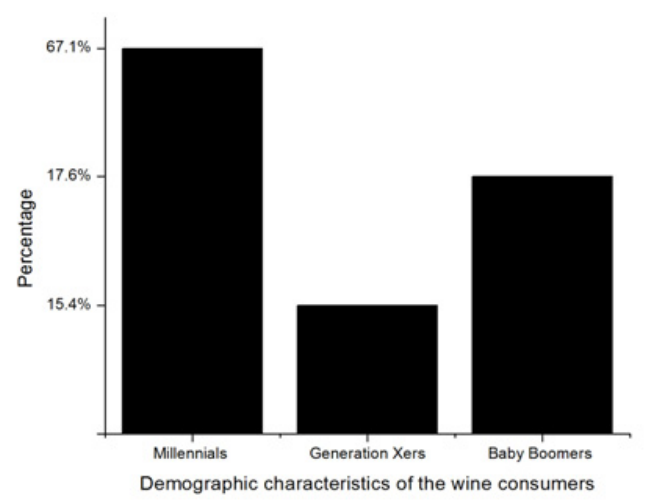

Figure 1. Percentage of Demographic characteristic of the wine consumers.

Table 2. Choice of wine attributes, as a relevant factor when making a decision about purchasing wine (A-attribute, B-Brend, Q-Quality; O-Origin, P-Price, PL- Packaging and Label).

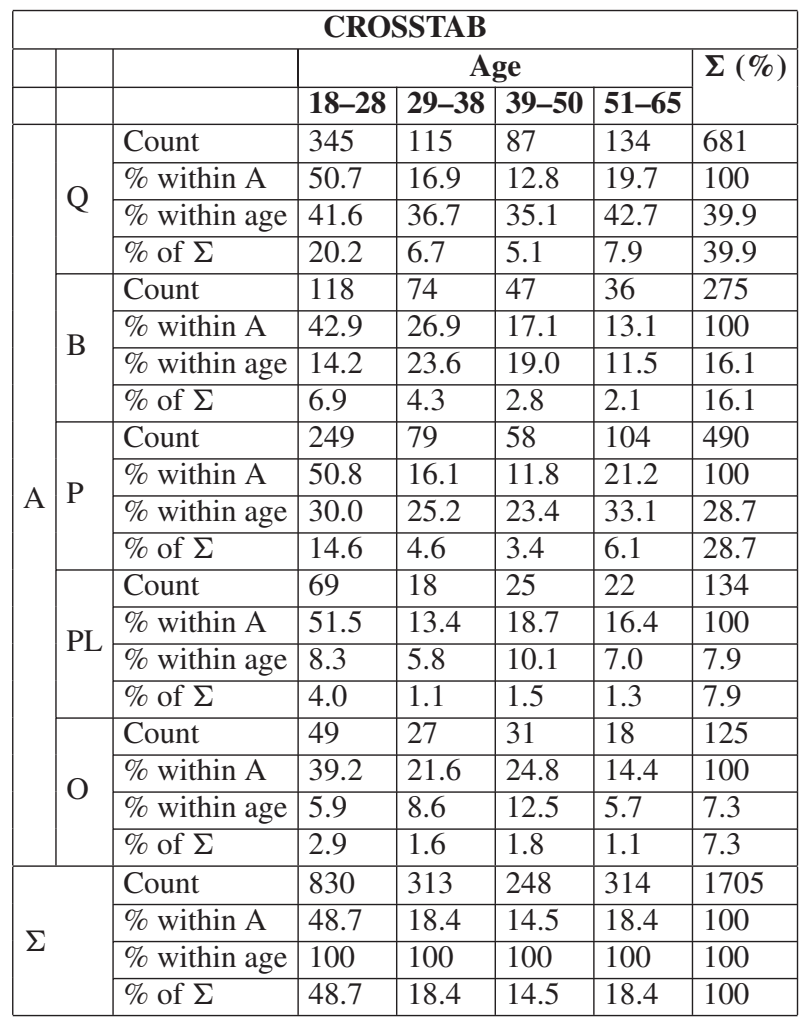

Source: Prepared by the authors (SPSS Statistics 19).

(chemical and sensory properties) of wine. This generation also their price is very important $(50.8 \%)$ when deciding to buy a wine and only $39.3 \%$ based on country of origin.

Generation $\mathrm{Y}_{1}$ can also be decided based on the reputation of wine ie brand wine, knowing that reputation is correlated with the quality of wines. Then, Generation X in deciding the purchase of wine to account for the origin of the wine $(24.8 \%)$, i.e. whether it is domestic or imported wine.

It can be concluded that quality and price it is a very important attribute in deciding the purchase of wine in all generations. Investigation is shows that $39.9 \%$ of all respondents make a decision to buy wine based on the quality. 
Table 3. Impact of age of consumers on purchasing of domestic+ or imported wine.

\begin{tabular}{|l|l|l|l|}
\hline \multicolumn{4}{|c|}{ CHI-SQUARE TESTS } \\
\hline & Value & $\begin{array}{l}\text { Asymp. } \\
\text { df }\end{array}$ & Sig (2 sid.) \\
\hline Pearson Chi-Square & $39.473^{\mathrm{a}}$ & 3 & .000 \\
\hline Likelihood Ratio & 37.335 & 3 & .000 \\
\hline Linear-by-Linear Association & .007 & 1 & .935 \\
\hline N of Valid Cases & 1705 & & \\
\hline \begin{tabular}{l} 
a. 0 cells (.0\%) have expected count less than 5. \\
The minimum expected count is 40.15. \\
\hline
\end{tabular}
\end{tabular}

Source: Prepared by the authors (SPSS Statistics 19).

Table 4. Purchasing wine of certain origin by age (D-Domestic, I-Imported, W-wine).

\begin{tabular}{|c|c|c|c|c|c|c|c|}
\hline \multicolumn{8}{|c|}{ CROSSTAB } \\
\hline & & & \multicolumn{4}{|c|}{ Age } & \multirow[t]{2}{*}{$\Sigma(\%)$} \\
\hline & & & $18-28$ & 29-38 & $39-50$ & $51-65$ & \\
\hline \multirow{8}{*}{ W } & \multirow{4}{*}{ D } & Count & 708 & 258 & 178 & 285 & 1429 \\
\hline & & \% within W & 49.5 & 18.1 & 12.5 & 19.9 & 100 \\
\hline & & $\%$ within age & 85.3 & 82.4 & 71.8 & 90.8 & 83.8 \\
\hline & & $\%$ of $\Sigma$ & 41.5 & 15.1 & 10.4 & 16.7 & 83.8 \\
\hline & \multirow{4}{*}{ I } & Count & 122 & 55 & 70 & 29 & 276 \\
\hline & & \% within $\mathrm{W}$ & 44.2 & 19.9 & 25.4 & 10.5 & 100 \\
\hline & & $\%$ within age & 14.7 & 17.6 & 28.2 & 9.2 & 16.2 \\
\hline & & $\%$ of $\Sigma$ & 7.2 & 3.2 & 4.1 & 1.7 & 16.2 \\
\hline \multirow{4}{*}{\multicolumn{2}{|c|}{$\Sigma$}} & Count & 830 & 313 & 248 & 314 & 1705 \\
\hline & & \% within $\mathrm{W}$ & 48.7 & 18.4 & 14.5 & 18.4 & 100 \\
\hline & & $\%$ within age & 100 & 100 & 100 & 100 & 100 \\
\hline & & $\%$ of $\Sigma$ & 48.7 & 18.4 & 14.5 & 18.4 & 100 \\
\hline
\end{tabular}

Source: Prepared by the authors (SPSS Statistics 19).

The lowest percentages of respondents who make a decision to buy wine on the basis of the country of origin are those older than 51 years $(5.7 \%)$.

The lowest percentage of respondents who make a decision to buy wine based on the packaging and label are those aged 29 to 38 years $(5.8 \%)$ and 39 to 50 years $(10.1 \%)$.

On the basis of the value of Sig., Table 3 shows that age has a significant influence in the choice of wine attributes, as a factor in making a decision about buying wine, because its value is less than 0.05 .

Regardless of the fact whether they buy wine of domestic or imported origin highest percentage of consumers $(39.9 \%)$ make a decision to buy wine based on its quality.

In addition, the authors carried out an analysis of the impact of age of consumers on the purchase of wine of a certain origin (Table 4):

Respondents of more than 51 years of age mostly buy domestic wine $(90.8 \%)$, while those 27 from 39 years of age (Generation Y) usually buy wine of imported origin $(28.2 \%)$.

Wine attributes that affect the consumers to buy wine of domestic origin are: $39.8 \%$ of respondents make this decision based on the quality of wine, $31.3 \%$ based on the price of wine, $15.4 \%$ based on the reputation or brand, $7.6 \%$ based on 20 the packaging and label, and only $5.9 \%$ based on the country of origin (Table 5).

Consumers who buy wine of imported origin start from the following attributes: quality (40.6\% of respondents),
Table 5. Purchasing wine of domestic or imported, based on wine attributes (A-attribute, B-Brend, D-Domestic, Q-Quality, I-Imported, O-Origin, P-Price, PL-Packaging and Label, Wwine).

\begin{tabular}{|c|c|c|c|c|c|c|c|c|}
\hline \multicolumn{9}{|c|}{ CROSSTAB } \\
\hline & & & \multicolumn{5}{|c|}{ Wine attributes } & \multirow[t]{2}{*}{$\Sigma(\%)$} \\
\hline & & & $\mathbf{Q}$ & $\mathbf{B}$ & $\mathbf{P}$ & $\mathbf{P L}$ & $\mathbf{O}$ & \\
\hline \multirow{8}{*}{ W } & \multirow{4}{*}{ D } & Count & 569 & 220 & 447 & 108 & 85 & 1429 \\
\hline & & $\%$ of $\mathrm{W}$ & 39.8 & 15.4 & 31.3 & 7.6 & 5.9 & 100 \\
\hline & & $\%$ of $\mathrm{A}$ & 83.6 & 80.0 & 91.2 & 80.6 & 68.0 & 83.8 \\
\hline & & $\%$ of $\Sigma$ & 33.4 & 12.9 & 26.2 & 6.3 & 5.0 & 83.8 \\
\hline & \multirow{4}{*}{ I } & Count & 112 & 55 & 43 & 26 & 40 & 276 \\
\hline & & $\%$ of $\mathrm{W}$ & 40.6 & 19.9 & 15.6 & 9.4 & 14.5 & 100 \\
\hline & & $\%$ of $\mathrm{A}$ & 16.4 & 20.0 & 8.8 & 19.4 & 32.0 & 16.2 \\
\hline & & $\% \Sigma$ & 6.6 & 3.2 & 2.5 & 1.5 & 2.3 & 16.2 \\
\hline \multirow{4}{*}{$\Sigma$} & & Count & 681 & 275 & 490 & 134 & 125 & 1705 \\
\hline & & $\%$ of $\mathrm{W}$ & 39.9 & 16.1 & 28.7 & 7.9 & 7.3 & 100 \\
\hline & & $\%$ of $\mathrm{A}$ & 100 & 100 & 100 & 100 & 100 & 100.0 \\
\hline & & $\%$ of $\Sigma$ & 39.9 & 16.1 & 28.7 & 7.9 & 7.3 & 100.0 \\
\hline
\end{tabular}

Source: Prepared by the authors (SPSS Statistics 19).

Table 6. Impact of wine attributes on the purchase of wine of domestic or foreign origin.

\begin{tabular}{|l|l|l|l|}
\hline \multicolumn{4}{|c|}{ CHI-SQUARE TESTS } \\
\hline & Value & df & $\begin{array}{l}\text { Asymp. } \\
\text { Sig. (2-sided) }\end{array}$ \\
\hline Pearson Chi-Square & $46.879^{\mathrm{a}}$ & 4 & .000 \\
\hline Likelihood Ratio & 45.865 & 4 & .000 \\
\hline Linear-by-Linear Association & 2.417 & 1 & .120 \\
\hline N of Valid Cases & 1705 & & \\
\hline $\begin{array}{l}\text { a. } 0 \text { cells (.0\%) have expected count less than 5. } \\
\text { The minimum expected count is 20.23 }\end{array}$ \\
\hline
\end{tabular}

Source: Prepared by the authors (SPSS Statistics 19).

brand $(19.9 \%)$, price of wine $(15.6 \%)$, country of origin (14.5\%), and packaging and label of wine 23 (19.4\%):

Regardless of the fact whether they buy wine of domestic or imported origin, the highest percentage of consumers make a decision to buy wine based on its quality of wine and brand of wine.

However, a larger number of Serbian consumers, because of the low purchasing power, make a decision to buy wine of domestic origin.

On the basis of the value of Sig. which is given in Table 6, we can conclude that the attributes of wine have significant impact on the choice of wine of domestic or imported origin.

\section{Conclusions}

Results of marketing research have shown that when choosing wine, the quality of wine has the biggest impact on consumers, rather than others wine attributes. The results of the research suggest that age Serbia's consumers have a significant impact, when making a decision about purchasing wine.

Based on Chi-test, the authors have been proven that the age affect the decision on the purchase of destined wine.

Starting from the obtained research results, the conclusion offers a recommendation for the implementation of successful strategies of the marketing mix instruments. 
The research was supported by the Ministry of Education and Science of the Serbia, No. project TR 31020 and TR 34012.

\section{References}

[1] P. Arsil, E. li, J. Bruwer, J Inter Food \& Agribus. Marketing 26(2), 107 (2014)

[2] J. Bruwer, E. Li, S. Lang, S. Chaumont, J Foodservice Bus. Res. 15(3), 300 (2012)

[3] P. Combris, S. Lecocq, M. Visser, The Economic J. 107(441), 390 (1997)

[4] S. Geraghty, A. Torres, A. Int J. Wine Business Res. 21(2), 143 (2009)
[5] M. Sanchez, J.M. Gil, Int. J Wine Marketing 10(1), $25(1998)$

[6] W. Zikmund, Exploring marketing research, $8^{\text {th }}$ ed. Chicago: Dryden Press Publ., 1999

[7] E. Tach, J. Olsen, Agribusiness 22(3), 307 (2006)

[8] G. Ordun, Canadian Social Science 11/4, 40 (2015)

[9] M. Hume, J. World Business 45/4, 385 (2010)

[10] J. Bruwer, M. House, The Australian \& New Zeland Grape grower \& winemaker 479, 56 (2003)

[11] L. Lancaster, D. Stillman, When generation sollide. New York: Harper Collins Publishing, 2002

[12] T. Atkins, L. Tach, Wine Economics and Policy 1(1), $54(2012)$ 